\title{
Aktualisasi Islam dan Keindonesiaan Dallam Koteks Ideologi Negara Pancasila
}

\author{
Masykuri Abdillah
}

\begin{abstract}
ABSTRAK
Indonesia adalah negara modern demokratis yang menjunjung tinggi posisi agama dalam kehidupan masyarakat dan negara. Secara institusional, negara Indonesia dibangun sebagai negara modern sekuler, tetapi secara filosofis, negara ini didasarkan pada Pancasila, yang sila pertamanya adalah Ketuhanan Yang Maha Esa. Pancasila dijadikan sebagai dasar negara demi membangun persatuan bangsa Indonesia oleh kelompok Islam dan kelompok nasionalis dengan melakukan kompromi yang disebut sebagai kesepakatan atau konsensus nasional (al-mîtsâq wathanî). Penerimaan tokoh Islam terhadap negara-bangsa berdasarkan Pancasila menunjukkan, bahwa watak Islam di Indonesia adalah moderat, yang sangat menghargai toleransi dan persatuan dalam keberagaman bangsa serta menerima NKRI. Hal ini ditunjukkan pula oleh organisasi-organisasi Islam besar, terutama NU dan Muhammadiyah, dalam amandemen UUD 1945 di awal era reformasi, yang tidak mendukung pencantuman Piagam Jakarta atau pelaksanaan syariat Islam dalam konstitusi.
\end{abstract}

\section{Kata Kunci : Islam, Indonesia, Pancasila, Demokrasi}

\begin{abstract}
Indonesia is neither a secular nor a religious state but a modern democratic country that respects the position of religion in the life of the nation and state. Political modernization in almost all countries in the world has given rise to political secularization, including in Islamic countries such as Saudi Arabia and Iran. Institutionally, the Indonesian state was developed as usual modern secular states, but philosophically, this country is based on the ideology of Pancasila, the first principle of which is Belief in God and the only God. Pancasila was used as the basis of the state to develop the unity of the Indonesian nation between Islamic groups and nationalist groups by making a compromise which is known as a national consensus (al-mîtsâq wathanî). The acceptance of Islamic figures towards the nation-state based on Pancasila shows that the characteristic of Islam in Indonesia is moderate, which highly appreciates tolerance and unity in the diversity. This was also demonstrated by major Islamic organizations, especially NU and Muhammadiyah, in the amendments to the 1945 Constitution in the early days of reform era, which did not support the inclusion of the Jakarta Charter or the implementation of shariah in the constitution.
\end{abstract}




\section{Keywords: Islam, Indonesia, Ideology, Pancasila}

\section{PENDAHULUAN}

Masyarakat Indonesia adalah masyarakat yang religius, yang ditunjukkan bahwa sebelum merdeka, di negara ini telah dibangun kerajaan-kerajaan yang berbasis agama. Namun di era modern, posisi agama dalam negara diperdebatkan, terutama antara kelompok Islam dengan kelompok nasionalis sekuler. Perdebatan ini terjadi pada sidang-sidang Badan Penyelidik Usaha Persiapan Kemerdekaan Indonesia (BPUPKI) pada 1945, yakni antara pendukung Islam sebagai dasar negara dan pendukung negara sekuler. Perdebatan ini berakhir dengan disepakatinya Pancasila sebagai dasar negara yang dimuat di dalam naskah Piagam Jakarta pada 22 Juni 1945. Sila pertama Piagam Jakarta itu berbunyi “Ketuhanan dengan berkewajiban menjalankan syariat Islam bagi pemeluk-pemeluknya." Namun hanya beberapa saat setelah proklamasi kemerdekaan Indonesia, 17 Agustus 1945, kelompok minoritas non-Muslim di Indonesia Timur menuntut penghapusan tujuh kalimat pada sila pertama ini. Akhimya pada 18 Agustus 1945, para wakil Islam setuju menghapus kalimat tersebut untuk menghindari perpecahan bangsa Indonesia yang baru saja memproklamasikan kemerdekaannya, tetapi sila pertama diubah menjadi "Ketuhanan Yang Maha Esa".

Perdebatan tersebut terulang lagi pada sidang-sidang Konstituante 1956-1959 hasil pemilihan umum (pemilu) 1955, yang berakhir dengan penerbitan Dekrit Presiden 5 Juli 1959 tentang "kembali ke UUD 1945". Dalam dekrit ini Piagam Jakarta disebutkan menjiwai terbentuknya UUD 1945 sebagai upaya untuk mengakomodasi sebagian dari aspirasi kelompok Islam. Perdebatan antara orientasi Keislaman dan orientasi Kebangsaan juga terjadi di masa-masa awal periode Orde Baru (1966-1998), yang kemudian menghasilkan kebijakan "deideologisasi" partai politik, terutama dalam bentuk pelarangan keberadaan partai agama atau berbasis agama dan menjadikan Pancasila sebagai satu-satunya asas bagi partai-partai politik dan organisasi-organisasi kemasyarakatan.

Di masa-masa awal era reformasi (1998-sekarang), perdebatan antara orientasi Keislaman dan orientasi Keindonesian juga terjadi, dan kini hal ini kadang kala terjadi. Perdebatan ini diperparah dengan munculnya kelompok sayap kanan (agama) di satu sisi, dan kelompok sekuler, yang ingin memisahkan sepenuhnya agama dari negara, atau bahkan ekstrem kiri, yang menolak orientasi keagamaan dan menuntut penghidupan kembali organisasi PKI. Dalam kasus-kasus tertentu, perdebatan itu berimplikasi pada munculnya ketegangan dalam pemilu atau pemilihan kepala daerah (pilkada), meski kemudian setelah selesainya pemilu dan pilkada, ketegangan itu menjadi redup atau hilang.

Pemerintah dan lembaga-lembaga negara lain serta kelompok-kelompok civil society, terutama ormas-ormas keagamaan, telah berupaya untuk menjaga persatuan, kedamaian, kerukunan, dan kedamaian dalam kehidupan masyarakat dan negara, baik melalui pendekatan politik, teologis, kultural, maupun yuridis. Dalam konteks 
ini, pembahasan akan ditekankan pada perspektif politik dan teologis, terutama aktualisasi ajaran-ajaran Islam di Indonesia yang berdasarkan Pancasila.

\section{PEMBAHASAN}

\section{Islam dan Negara Pancasila}

Di era modern ini relasi antara agama dan negara dapat dikelompokkan ke dalam tiga bentuk, yakni penyatuan antara agama dan negara, pemisahan antara agama dan negara, serta persinggungan antara agama dan negara. ${ }^{\mathrm{i}}$ Pemisahan antara agama dan negara di negara demokratis sekuler sangat bervariasi. Hanya Prancis dan Amerika Serikat (AS) yang memiisahkan secara tegas, sedangkan penerapan sekularisme di negara-negara Eropa umumnya kurang ketat. Dalam beberapa kasus, keterlibatan negara dalam urusan keagamaan sangat jelas, misalnya penetapan hari raya keagamaan sebagai hari libur nasional, pengajaran agama di sekolah, subsidi negara kepada komunitas keagamaan, pungutan negara atas pajak gereja, dan sebagainya.. Bahkan agama kerap terlibat dalam politik, termasuk kampanye pemilihan umum.

Dalam konteks negara, Indonesia merupakan negara demokrasi modern yang terus mempertahankan posisi agama dalam kehidupan bermasyarakat dan bernegara.. Walaupun secara kelembagaan negara Indonesia dibangun sebagai negara sekuler modern, namun secara filosofis negara tersebut berlandaskan Pancasila yang sila pertamanya adalah Ketuhanan Yang Maha Esa. Sila pertama ini juga disebutkan secara eksplisit dalam pasal 29 ayat 1 UUD 1945, yakni "Negara berdasar atas Ketuhanan Yang Maha Esa". Pancasila merupakan kompromi antara dua kelompok aspirasi, yaitu kelompok Islam yang mendukung Islam sebagai dasar negara dan kelompok nasionalis yang mendukung Indonesia sebagai negara sekuler. ${ }^{\text {ii }}$ Memang di sejumlah negara Muslim, Islam menjadi agama resmi dan hukum Islam menjadi hukum nasional atau sumber utama hukum nasional. Namun demikian, kondisi di negara ini tidak memungkinkan untuk posisi ini, karena bangsa Indonesia adalah bangsa yang majemuk, baik dari segi suku, budaya, ras maupun agama. Demi membangun persatuan bangsa Indonesia, kelompok Islam dan kelompok nasionalis kemudian melakukan kompromi dengan menjadikan Pancasila sebagai dasar negara, yang selanjutnya disebut sebagai kesepakatan atau konsensus nasional tentang ideologi negara. Dengan demikian, Pancasila merupakan dasar statis yang mempersatukan sekaligus bintang penuntun yang dinamis, yang mengarahkan bangsa Indonesia dalam mencapai tujuaannya. ${ }^{\text {iii }}$

Meski demikian, sampai kini masih ada kelompok minoritas dalam umat Islam yang mempersoalkan Pancasila dan menganggapnya tidak sesuai dengan Islam. Dalam perspektif Islam, suatu perjanjian, konsensus atau kesepakatan nasional (almîtsâq al-wathanî), bisa mengikat selama tidak bertentangan dengan ajaran-ajaran agama. Hal ini berdasarkan pada praktik Nabi di masa-masa awal kedatangan di Madinah yang melakukan kesepakatan atau perjanjian bersama dengan kelompokkelompok sosial yang merupakan penduduk asli Madinah. Kesepakatan bersama untuk membangun sebuah masyarakat dan negara yang damai itu diformulasikan dalam bentuk Piagam Madinah (Wathîqah al-Madînah atau Mîthaq al-Madînah). Karena adanya kesepakatan di antara para founding fathers negara Indonesia, $\mathrm{KH}$ Ma'ruf 
Amin menyebut negara ini sebagai Darul Mitsaq (Dâr al-Mîtsâq), yang berarti Negara Kesepakatan atau Konsensus, ${ }^{\text {iv }}$ sedangkan Muhammadiyyah menyebutnya sebagai Darul 'Ahdi was-Syahadah (Dâr al-'Ahd wa al-Syahâdah), yang berarti Negara Kesepakatan dan Kesaksian. Sedangkan Nahdlatul Ulama telah memberikan nama negara ini pada tahun 1938, yakni Darus Salam (Dâr al-Salâm), yang berarti Negara Damai, dan istilah ini sebenarnya masih dipertahankan sampai sekarang walaupun tidak banyak disebutkan dalam berbagai kesempatan.

Argumentasi tersebut sekaligus menolak argumentasi pendukung Negara Islam (daulah Islâmiyyah) atau Negara Khilafah yang menganggap negara Pancasila bertentangan dengan Islam. Khilafah memang menjadi sistem kenegaraan yang dipraktikkan sejak masa Al-Khulafa' al-Rasyidun sampai Dinasti Utsmani, tetapi sistem ini sebenarnya hanya peristiwa sejarah, bukan ajaran Islam yang bersifat qath' $\hat{\imath}$ (pasti atau absolut). Bahkan setelah periode Al-Khulafa' al-Rasyidun, praktik-praktik khilafah ini tidak sepenuhnya sesuai dengan ajaran Islam, misalnya kepemimpinan yang turun temurun dan kecenderungan otoritarianisme pada sebagian besar pemimpinnya. Dalam konteks kenegaraan, Islam sebenarnya hanya mengajarkan prinsip-prinsip umum saja dan pelaksanaan syariat Islam. Prinsip-prinsip ini adalah keadilan (al-'adâlah), kejujuran dan tanggung jawab (al-amânah), persaudaraan (alukhuwwah), menghargai kemajemukan (al-ta'adduddiyyah), (persamaan (al-musâwah),

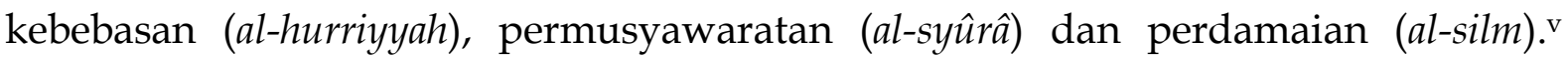
Dalam persoalan kenegaraan ini Islam tidak mengajarkan hal-hal yang bersifat teknis operasional, seperti bentuk negara, bentuk pemerintahan, bentuk perwakilan, bentuk pengadilan, dan sebagainya. Hal-hal ini ditetapkan oleh umat Islam sendiri berdasarkan prinsip maslahah, yakni sistem yang terbaik dan bermanfaat bagi umat dan kemanusiaan sesuai dengan perkembangan dan tantangan zaman.

Sila pertama Pancasila, yakni Ketuhanan Yang Maha Esa, mengandung arti pengakuan terhadap eksistensi agama dalam kehidupan masyarakat dan bernegara. Dalam konteks negara, pengakuan ini diwujudkan dalam bentuk formalisasi institusiinstitusi keagamaan tertentu sebagai institusi kenegaraan serta adopsi sebagian nilainilai dan norma-norma agama sebagai hukum nasional atau sebagai input dalam pengambilan kebijakan publik (public policy). Eksistensi agama ini tidak akan hilang, meski negara ini telah melakukan pembangunan dan modernisasi di berbagai bidang sebagai upaya untuk meningkatkan kesejahteraan rakyat dan memajukan bangsa.

Sebagaimana diketahui, bahwa modernisasi politik di hampir semua negara di dunia telah melahirkan sekularisasi politik, termasuk di negara-negara Muslim yang sangat kental dengan orientasi keagamaan. Dalam kaitan dengan hal ini, Donald Eugen Smith beberapa dekade lalu mengatakan, bahwa sebenarnya sekularisasi politik dan pelibatan agama dalam politik ini berjalan secara simultan. Namun menurut dia, sekularisasi ini betul-betul merupakan proses yang lebih mendasar, dan hal ini lambat laut akan melenyapkan fenomena partai politik dan ideologi keagamaan.vi Dalam kenyataannya, umat Islam di berbagai negara Muslim tetap memiliki orientasi agama dalam kehidupan masyarakat dan bernegara. Hal ini memang tidak terlepas dari karakteristik ajaran Islam itu sendiri, yang tidak hanya merupakan sistem teologis, tetapi juga cara hidup (way of life) yang mencakup standar etika-moral (akhlak) dan norma-norma dalam kehidupan masyarakat dan negara. 
Oleh karena itu, proses modernisasi dan bahkan sekularisasi di negara-negara Muslim secara umum tidak sampai menghilangkan orientasi keagamaan dalam kehidupan masyarakat dan negara. ${ }^{\text {vii }}$

Pemerintah Orde Baru di bawah presiden Soeharto memang melakukan sekularisasi politik yang sangat kuat, terutama dengan kebijakan "deideologisasi politik". Hanya saja, dalam kehidupan masyarakat tidak terjadi sekularisasi secara radikal, karena umat Islam tetap memiliki orientasi keagamaan yang kuat, sementara perjuangan umat dilakukan secara kultural melalui pendidikan dan dakwah. Orientasi ini berimplikasi bahwa proses modernisasi di negara ini tidak sampai menjadikan negara ini menjadi negara sekuler. Pendekatan kultural ini pun kemudian bisa mempengaruhi kebijakan pemerintah, yang dalam dekade terakhirnya melakukan revisi kebijakan yang lebih akomdatif terhadap Islam.

Jatuhnya pemerintahan Orde Baru dan munculnya Era Reformasi pada 1998, dijadikan sebagai momentum bagi sebagian tokoh Islam untuk menegaskan kembali pentingnya politik Islam dengan mendirikan partai-partai Islam atau partai-partai berbasis massa ormas Islam. Pada saat itu memang terjadi perdebatan di antara tokoh dan intelektual Muslim, yakni antara mereka yang mendukung partai Islam dan yang menolaknya. Namun pendirian partai-partai agama tetap berlangsung, karena dalam sistem demokrasi, pendirian partai agama itu dibenarkan, sebagaimana yang juga terjadi di negara-negara Eropa. Di samping itu, di masa-masa awal era reformasi, terutama dalam konteks amandemen UUD 1945, muncul gagasan dan perdebatan untuk memasukkan semangat Piagam Jakarta atau pelaksanaan syari'at Islam dalam konstitusi. Namun ormas-ormas Islam besar, terutama NU dan Muhammadiyah, tidak mendukung gagasan atau usulan itu dan tetap mempertahankan rumusan yang terdapat dalam pasal 29 UUD 1945.

Hal tersebut menunjukkan, bahwa karakteristik Islam di Indonesia adalah Islam yang moderat, toleran, dan damai, baik dalam konteks kehidupan masyarakat, konteks negara dan sistem demokrasi, maupun konteks kehidupan modern yang cukup akomodatif. Pada saat ini Indonesia bahkan dinilai sebagai negara Muslim yang paling toleran dan paling demokratis di dunia, sehingga banyak tokoh dunia dan intelektual Muslim yang menginginkan negara ini menjadi model bagi negara Muslim modern yang demokratis tetapi tetap menghargai posisi agama.

Persoalan-persoalan yang kadang-kadang muncul, terutama diekspresikan oleh kelompok fundamentalis, radikal, atau ekstrem meliputi: (1) sistem negara bangsa yang dibenturkan sistem negara khilafah, (2) ideologi Pancasila yang dibenturkan dengan ideologi Islam, (3) sistem demokrasi yang dibenturkan dengan "sistem teokrasi", dan (4) sistem hukum sekuler dengan sistem hukum Islam. Sebenarnya sejak awal kemerdekaan, para tokoh Islam, terutama yang menjadi founding fathers sudah melakukan upaya-upaya harmonisasi terhadap persoalan-persoalan tersebut. Demikian para ulama dan intelektual Muslim pada saat ini juga telah berusaha melakukan harmonisasi antara agama dan negara dengan berbagai aspeknya, baik secara normatif maupun akademik.

Harmonisasi itu dilakukan di samping penjelasan tentang kompatibilitas Pancasila dan NKRI dengan ajaran Islam, juga penjelasan tentang pembangunan hukum nasional. Dalam hal ini, hukum Islam menjadi salah satu sumber dalam 
legislasi nasional, di samping hukum adat, hukum internasional, dan hukum Barat. Di negara ini hukum Islam bisa dilegislasi secara formal menjadi hukum nasional, seperti hukum perkawinan, hukum zakat dan wakaf, hukum ekonomi Islam, dan sebagainya. Jika tidak bisa dilegislasi secara formal, substansi atau esensi hukum Islam bisa diintegrasikan atau diserap ke dalam legislasi hukum nasional.

\section{Islam dan Demokrasi Indonesia}

Secara historis demokrasi lahir dari paham pemisahan antara agama dan negara (sekularisme), sebuah paham yang pertama kali dikemukakan oleh Niccolo Machiavelli (1469-1527). Dengan demikian, bisa dimaklumi jika pada saat ini masih ada perdebatan tentang afinitas agama dan demokrasi. Hal ini terjadi karena dalam persepktif sekularisme dan modernisasi, agama berpotensi menjadi instrumen untuk bertindak secara otoriter yang menjadi halangan bagi pencapaian "modernitas dan rasionalitas", yang notabene merupakan prasyarat bagi terwujudnya demokrasi. viii Memang terdapat perbedaan di kalangan ilmuwan politik dan pengamat tentang kompatibilitas atau afinitas agama dan demokrasi. Sebagian dari mereka berpendapat bahwa agama dan demokrasi itu berlawanan, tetapi banyak juga yang berpendapat bahwa agama dan demokrasi dapat kompatibel jika agama dipahami secara moderat dan progresif.ix

Dalam praktiknya, sekularisme di negara-negara Eropa Barat sebenarnya tidak terlalu ketat, sehingga di sejumlah negara terdapat intervensi atau keterlibatan negara dalam urusan-urusan agama tertentu, seperti keberadaan agama resmi yang secara eksplisit disebutkan dalam konstitusi, pendidikan agama di sekolah-sekolah negeri, subsidi negara untuk agama, pungutan pajak gereja oleh negara, dan lain-lain. Bahkan beberapa negara Eropa memiliki gereja resmi (established church) yang diatur oleh negara, yakni Inggris, Norwegia, Denmark, Finlandia, Swedia, dan Yunani. ${ }^{x}$

Dalam teorinya, "twin tolerations", Alfred Stepan menguraikan hubungan agama dan negara dalam konteks sistem demokrasi, yang mencakup sikap umat beragama terhadap negara serta kebijakan negara terhadap umat beragama. Menurut Stepan, terdapat empat jenis pola demokratis tentang hubungan agama dan negara, yakni (1) sekuler tetapi ramah agama (secular but friendly of religion), (2) non-sekuler tetapi ramah dengan demokrasi (non-secular but friendly to democracy), (3) sekularisme spontan secara sosiologis) sociologically spontaneous secularism, dan (4) sekularime yang sangat tidak ramah yang diatur oleh mayoritas tetapi dapat dibatalkan oleh mayoritas juga (very unfriendly secularism legislated by majority but reversible by majority). ${ }^{\mathrm{x}}$ Dalam perspektif teori ini, relasi agama-negara di Indonesia bisa disebut sebagai non-secular but friendly to democracy (negara non-sekuler tetapi bersahabat dengan demokrasi).

Karena di sebagian besar negara di dunia selain negara-negara komunis, agama tidak bisa dipisahkan sepenuhnya dari negara, maka agama pun tidak bisa dipisahkan sepenuhnya dari politik dan sebaliknya. Pelibatan agama dalam politik tidak bertentangan dengan demokrasi, dan hal ini pun terjadi di negara-negara Barat yang notabene sekuler. Pelibatan ini dimaksudkan agar politik sesuai dengan etika dan ajaran agama, baik dalam hal perjuangan mendapatkan kekuasaan maupun dalam hal menggunakan kekuasaan untuk mewujudkan keadilan dan kesejahteraan rakyat. Di samping itu, pelibatan agama juga dimaksudkan untuk alat legitimasi 
aspirasi politik warga atau partai serta alat kritik sosial dan politik sebagai perwujudan amr ma'ruf nahy munkar (menyeru kepada kebaikan dan mencegah kemunkaran).

Agama bahkan bisa menjadi alat pemersatu dalam membangun identitas dan solidaritas sosial dalam kehidupan politik. Hanya saja, fungsi membangun identitas dan solidaritas sosial ini kini diperdebatkan, karena dalam beberapa tahun terakhir ini terjadi fenomena di dunia, termasuk di negara-negara Barat, yang mempraktikkan fungsi ini secara sempit, terutama munculnya politik identitas dan populisme yang tidak toleran terhadap kelompok lain.xii Pelibatan agama dalam politik identitas ini kemudian disebut sebagai politisasi agama yang berkonotasi negatif dan dinilai tidak sejalan dengan etika demokrasi, karena menggunakan sentimen agama untuk tujuantujuan politik secara tidak proporsional.

Memang benar terkadang muncul masalah dalam memadukan atau mengharmoniskan agama dan demokrasi, namun masalah seperti itu juga terjadi dalam memadukan atau mengharmoniskan demokrasi dan budaya non-Barat. Sebenarnya tidak ada masalah serius bagi negara Muslim untuk melaksanakan demokrasi secara substantif, yang mempromosikan kebebasan dan toleransi politik. Masalah muncul hanya jika tidak ada kemauan politik (political will) pemerintah untuk menganut sistem demokrasi secara substantif atau jika ada ideologi radikal atau ekstrem dari kelompok agama tertentu yang mengklaim kelompok mereka sendiri sebagai satu-satunya kebenaran, sedangkan yang lain adalah salah dan dianggap sebagai musuh.

Sebagai negara yang mayoritas $(87 \%)$ penduduknya beragama Islam, Indonesia sejak awal sudah dinyatakan sebagai negara demokratis, walaupun dalam praktiknya ia mengalami pasang surut. Munculnya era reformasi menyusul tumbangnya rezim Orde Baru pada 1998 menjadi titik awal bagi transisi menuju demokrasi yang substantif. Menurut Juan Linz dan Alfred Stepan, proses demokratisasi ini meliputi dua tahap, yakni transisi demokrasi dan konsolidasi demokrasi. ${ }^{\text {xiii }}$ Transisi ini telah berhasil dilalui dengan baik dan berakhir dengan suksesnya penyelenggaraan pemilu langsung yang pertama pada 2004.

Tahun 2004 sampai sekarang merupakan tahap konsolidasi demokrasi. Walaupun pemerintah tetap mendukung pelaksanaan demokrasi secara substantif, dalam kenyataannya, tahap ini kini masih menghadapi banyak problem dan hambatan menuju demokrasi yang beradab. Di antaranya adalah masih adanya praktik korupsi baik di kalangan lembaga eksekutif, legislatif dan yudikatif, politik uang, konflik dalam pemilu dan pilkada, konflik komunal, intoleransi, kekerasan, dan sebagainya. Kondisi ini terutama disebabkan oleh faktor lemahnya etika-moral, baik di kalangan politisi, birokrat dan masyarakat, serta distorsi dalam pemahaman ajaran agama. Di samping itu, keberadaan sistem politik dan sistem birokrasi kini masih mengandung kelemahan, sehingga memunculkan politik biaya tinggi dan kurang efektifnya sistem kontrol, yang kemudian menimbulkan politik uang dan korupsi.

Hal tersebut diperburuk dengan masih rendahnya pendidikan dan kesejahteraan warga serta munculnya radikalisme keagamaan yang mengancam kebebasan dan toleransi. Di sisi lain, kini masih muncul "demokrasi retorik", yakni adanya retorika tentang perlunya demokrasi yang beradab yang disampaikan oleh 
para politisi, tokoh masyarakat, ilmuwan dan intelektual, tetapi dalam kenyataannya, banyak dari mereka enggan mempraktikkan demokrasi sesuai yang dipidatokan itu ketika mereka mendapatkan kesempatan menjadi anggota legislatif atau memimpin sebuah lembaga atau organisasi.

Secara umum, ulama, ormas Islam dan intelektual muslim Indonesia mendukung sistem demokrasi, tetapi di era reformasi ini ekspresi kelompok yang menolak demokrasi semakin terbuka. Mayoritas ormas Islam di negara ini, seperti NU, Muhammadiyah, Alwasliyah, mendukung sistem demokrasi. xiv Hanya sebagian kecil ormas Islam yang menolaknya, seperti Hizbut Tahrir, Jamaah Ansharut Tauhid (JAT), pengikut Ikhwan Quthbiyyah, kelompok Salafi ekstrim, dan sebagainya. Pada tahun 2010 Hizbut Tahrir, misalnya, menerbitkan sebuah buku berjudul Ilusi Negara Demokrasi. Kemudian pada Maret 2013 lalu majalah Al-Wa'ie milik organisasi ini terbit dengan judul Demokrasi Sistem Kufur. ${ }^{x v}$ Mereka pun berdalih bahwa carut marut politik, korupsi dan kemiskinan pada saat ini adalah akibat dari sistem demokrasi. Walaupun jumlah mereka hanya minoritas, tetapi propaganda anti-demokrasi di berbagai media dan forum bisa berdampak luas. Pada pemilu-pemilu yang lalu, kelompok ini bahkan mengajak warga untuk tidak ikut berpartisipasi dalam pemilu, karena pemilu merupakan bagian dari sistem demokrasi, dan mengikuti pemilu berarti mengikuti sis kufur atau thaghût.

Oleh karena itu, upaya-upaya sosialisasi dan pendidikan demokrasi perlu terus menerus dilakukan, terutama dengan pendekatan keagamaan yang dilakukan oleh elemen-elemen Islam moderat. Program-program pendidikan politik dan demokrasi juga perlu dilakukan sebagai bagian dari pendidikan kewarganegaraan (civic education). Di samping itu, diperlukan pula upaya-upaya untuk menghilangkan ekses kebebasan melalui penguatan etika-moral bangsa, penguatan sistem dan budaya politik yang bermoral dan akuntabel serta penguatan penegakan hukum (law enforcement) yang adil dan serius. Lebih dari itu, komitmen pemerintah, para elit politik, tokoh masyarakat, ilmuwan dan intelektual untuk membangun sistem demokrasi yang beradab hendaknya tidak hanya sebatas retorika, tetapi juga ditunjukkan dengan sikap dan tindakan mereka. Keteladanan ini sangat penting untuk mempermudah sosialisasi demokrasi serta pembentukan budaya dan etika demokratis.

\section{Problem Eskspresi Keagamaan}

Berakhirnya era Orde Baru dan lahirnya era reformasi ditandai dengan pembukaan kran kebebasan bagi warga negara untuk mengekspresikan pendapat, aspirasi, dan kepentingan mereka secara bebas dan terbuka. Bahkan di awal-awal era reformasi terdapat aspirasi atau tindakan warga yang berlebihan, sehingga hal ini kadang-kadang memunculkan ketegangan, perselisihan, konflik, dan bahkan kekerasan dalam masyarakat, baik yang bersifat horisontal maupun vertikal. Hal ini antara lain dipicu oleh adanya perbedaan-perbedaan aspirasi atau kepentingan, baik yang berlatarbelakang politik, ekonomi, etnis, maupun agama.

Memang diakui juga bahwa di era reformasi ini, peristiwa ketegangan atau konflik horizontal (antar-warga), termasuk yang berlatarbelakang agama, lebih banyak dibandingkan dengan pada masa Orde Baru. Demikian pula, ketegangan atau 
konflik vertikal (antara warga dan pemerintah/negara) juga semakin sering terjadi. Di samping karena adanya kebijakan Orde Baru yang menggunakan pendekatan keamanan (security approuch) dalam menangani perbedaan-perbedaan tersebut, juga karena masih adanya kebijakan-kebijakan negara yang dinilai tidak sejalan dengan aspirasi mereka. Walaupun merupakan masyarakat majemuk, yang notabene memiliki latar belakang, aspirasi, dan kepentingan yang sangat bervariasi, bangsa Indonesia kini tetap dikenal sebagai masyarakat yang toleran, termasuk dalam kehidupan beragama. Bahkan kerukunan umat beragama di negara ini menjadi contoh toleransi beragama di dunia.

Di sisi lain, perselisihan, konflik, atau kekerasan tersebut tidak terlepas dari munculnya paham-paham dan gerakan-gerakan keagamaan tansnasional yang intoleran, baik yang berbentuk konservatisme, radikalisme, maupun ekstremisme. Di kalangan masyarakat Islam, paham-paham dan perilaku ini tidak bisa dilepaskan dari ideologi atau paham Salafi/Wahhabi (dibangun oleh Syaikh Muhammad bin Abdul Wahhab pada abad ke-18) dan Al-Ikhwan al-Muslimun (didirikan oleh Hasan alBanna pada 1928 di Mesir), dan kemudian Hizbut Tahrir (didirikan oleh Taqiyyuddin al-Nabhani pada 1953 di Palestina).

Masing-masing kelompok tersebut adakalanya yang berperilaku cukup moderat, tetapi ada juga yang berperilaku radikal, intoleran, dan bahkan ekstrem. Mereka yang berperilaku ekstrem ini terpengaruh oleh ideologi Al-Qaedah dan ISIS, yang sebenarnya merupakan penggabungan paham Syaikh Muhammad bin Abdul Wahhab dan paham Sayyid Quthb.xvi Al-Qaedah didirikan pada 1988 oleh Abdullah Azzam dan Osama bin Laden serta veteran mujahidin Afghanistan setelah selesainya perang melawan rejim komunis di negara ini yang didukung Uni Soviet, sedangkan ISIS merupakan sempalan dari Al-Qaedah pada 2014 di bawah kepemimpinan Abu Bakar Al-Baghdadi. Secara akidah, mereka berideologi Salafi, sedangkan garis perjuangan mereka dipengaruhi oleh ideologi jihad ofensif yang dipromosikan oleh Sayyid Quthb. Ideologi Al-Qaedah dan ISIS ini kemudian menyebar ke seluruh dunia, termasuk ke Indonesia dengan munculnya gerakan-gerakan ekstrem seperti Jama'ah Islamiyyah (JI) yang berdiri pada tahun 1993 dan Jama'ah Ansharud Daulah (JAD) pada tahun 2014.

Dalam masyarakat yang majemuk, upaya mewujudkan persatuan, harmoni, dan kedamaian ini tidaklah mudah, karena masing-masing kelompok memiliki aspirasi dan kepentingan yang bisa berbeda-beda dan bisa berimplikasi kepada munculnya persaingan atau konflik. xvii Hal ini bisa menjadi nyata jika masing-masing kelompok menunjukkan egoisme kelompoknya dengan menunjukkan politik identitasnya secara eksklusif atas nama kebebasan. Dalam kehidupan masyarakat dan negara, adanya perbedaan, perselisihan, dan konflik sebenarnya merupakan hal yang alamiah yang tak bisa dihindarkan. Agar hal ini tidak menjadi konflik kekerasan, negara dan para tokoh masyarakat berkewajiban untuk mengelola hal ini, baik melalui penguatan nilai-nilai sosial maupun melalui penegakan hukum dan kebijakan negara yang kondusif.

Di antara konflik-konflik sosial yang terjadi, konflik berlatarbelakang agama merupakan konflik yang paling mengkhawatirkan, karena konflik ini juga didasarkan pada motivasi dan keyakinan pelakunya untuk mendapatkan pahala di akhirat kelak. 
Konflik berlatarbelakang agama ini adakalanya bersifat internal umat beragama dan adakalanya antarumat beragama. Konflik internal agama secara umum terkait dengan reaksi terhadap pemahaman keagamaan yang menyimpang atau pemahaman puritan yang menganggap kelompok lain sebagai pelaku bid'ah dan bahkan sesat. Sedangkan konflik antarumat beragama umumnya terkait dengan faktor persaingan politik, ekonomi, atau lainnya yang kemudian dikaitkan dengan agama. Dalam kasuskasus tertentu, faktor agama juga mempengaruhi terjadinya perselisihan, tetapi secara umum bukan karena faktor dokrin keagamaan, melainkan persoalan pendirian rumah ibadah dan penyiaran agama yang tidak sesuai dengan peraturan, serta penodaan (penghinaan) agama. Memang sebagian dari persoalan ini dipengaruhi oleh doktrin atau prinsip aliran Salafi tentang hubungan sosial, yakni al-walấ wa albarấ.xviii Prinsip al-walấ berarti hubungan saling mencintai antar sesama Muslim, sedangkan al-barâ' berarti hubungan lepas diri atau kebencian dalam hubungan antara Muslim dengan non-Muslim. ${ }^{\text {xix }}$

Ketegangan atau konflik antar kelompok yang melibatkan agama dalam politik terutama terkait dengan pemilu/pilkada dan persaingan rekrutmen jabatan publik. Sebenarnya keterlibatan warga dalam pemilu/pilkada merupakan suatu bentuk partisipasi politik rakyat yang bersifat positif, yang menjadi salah satu indikator demokrasi. Dalam perspektif demokrasi, aspirasi rakyat itu perlu disalurkan secara individual atau melalui partai-partai politik yang menjadi peserta pemilu/pilkada. Dalam hal ini partai-partai politik dituntut untuk melakukan peran secara optimal, baik dalam hal sosialisasi politik maupun artikulasi dan agregasi kepentingan konstituennya. Aspirasi rakyat bisa juga disalurkan juga melalui saluran sekunder, yakni melalui organisasi-organisasi civil society, yang keberadaanya sangat dibutuhkan dalam sistem demokrasi, seperti ormas-ormas keagamaan dan lembaga swadaya masyarakat (LSM).

Berbeda dengan era Orde Baru, di era reformasi proses politik dalam sistem demokrasi, khususnya pemilu / pemilihan kepala daerah dan pembentukan kebijakan publik, dilakukan secara bebas dan terbuka. Hal ini untuk memungkinkan otoritas legislatif dan yudikatif mengelola dan menyelesaikan persaingan atau konflik kepentingan secara beradab. Pemilu yang berlangsung di era reformasi bersifat demokratis, adil, adil dan damai, menjadikan Indonesia negara Muslim paling demokratis di dunia. Memang dalam beberapa hal masih terdapat kelemahan dalam penyelenggaraan pilkada / pilkada, seperti manipulasi voting, kebijakan moneter, konflik atau ketegangan antar warga, "politisasi agama" dan lain sebagainya. Hal ini dapat mengarah pada rekayasa politik yang mengubah keinginan minoritas tertentu atau elit politik menjadi keinginan mayoritas.

Seperti disebutkan di atas, memasukkan agama ke dalam politik tidak bertentangan dengan demokrasi, dan hal yang sama berlaku di negara-negara Barat sekuler, termasuk Amerika Serikat, baik dalam bentuk partai politik maupun dalam kontesatasi politik dan pengambilan kebijakan publik. Pelibatan ini dibenarkan jika tidak mengarah kepada "politisasi agama" dan tidak pula menimbulkan kebencian dan konflik antarkelompok. Politisasi agama yang dimaksud adalah penyalahgunaan agama, issu-issu atau simbol-simbol keagamaan sebagai alat untuk memperoleh 
tujuan-tujuan politik, terutama untuk memenangkan calon tertentu dalam pemilihan jabatan publik. $x x$

Di antara penggunaan issu-issu agama yang dianggap cukup menegangkan dan mengkhawatirkan adalah pilkada DKI 2017 Jakarta dan pemilihan Presiden 2019. Pilkada dan pemilu ini semula dikhawatirkan dapat merusak harmoni sosial dan kerukunan umat beragama, namun ternyata pelaksanaannya berjalan dengan lancar dan damai. Memang diakui, bahwa persaingan politik pada pilkada DKI Jakarta 2017 dan pilpres 2019 yang lalu telah melahirkan munculnya gesekan antarkelompok dalam masyarakat, tetapi setelah selesai pilkada/pemilu, gesekan itu pun hampir sepenuhnya pudar. Hal ini berarti bahwa meski terdapat persoalan-persoalan dalam ekspresi kebebasan keagamaan sebagaimana disebutkan di atas, dalam kenyataannya, pemilu/pilkada di era refomasi ini berjalan dengan lancar dan damai.

\section{Penguatan Wawasan Kebangsaan}

Untuk menjaga integrasi nasional tersebut, semua unsur dalam masyarakat dituntut untuk memperkuat wawasan kebangsaan (nasionalisme) dan menjaga NKRI dari segala ancaman yang bisa merusaknya. Di kalangan masyarakat Islam, umumnya nasionalisme dipahami dalam konteks perjuangan kemerdekaan melawan penjajah, dan pemahaman ini tidak dipersoalkan oleh ulama dan tokoh Islam, bahkan mereka mendukungnya sebagai suatu kewajiban dengan dasar ayat-ayat jihad yang mengharuskan umat Islam mempertahankan diri dari serangan musuh. Di samping, wawasan kebangsaan juga didasarkan pada hadits (dha'if) hubb al-wathan min al-îmân (cinta tanah air merupakan bagian dari iman).

Di Indonesia paham kebangsaan ini masih tetap dipupuk sampai sekarang, meski terdapat variasi dalam retorika dan aktualisasinya. Namun dalam perkembangannya untuk menghaluskan paham ini agar tidak terkesan sebagai sebuah ideologi, kata ini dikembangkan menjadi wawasan kebangsaan, yang berarti cara pandangan atau orientasi seseorang terhadap negara-bangsa sebagai satu kesatuan ideologis dalam bentuk Pancasila, kesatuan yuridis berdasarkan UUD 1945, kesatuan geografis dalam bentuk negara kesatuan republik Indonesia (NKRI) dan kesatuan demografis sebagai negara yang penduduknya sangat majemuk. xxi

Dengan cara pandang ini, seorang warga negara dituntut untuk mewujudkan persatuan dengan mendahulukan kepentingan bangsa daripada kepentingan kelompok atau individu. Hal ini penting, karena dalam masyarakat yang majemuk, yang berimplikasi bahwa masing-masing kelompok memiliki aspirasi dan kepentingan yang variasi, diperlukan adanya persamaan visi dan orientasi di antara mereka, yakni wawasan tentang hubungan antarwarga yang didasarkan pada persaudaraan dan persatuan dengan mengembangkan sikap saling menghormati dan saling mengakui keberadaan masing-masing. Dan untuk mewujudkan wawasan kebangsaan ini, warga negara perlu memahami filosofi, sejarah, dan kondisi sosiokultural masyarakat Indonesia.

Di era reformasi ini muncul sejumlah tantangan terhadap wawasan kebangsaan ini melebihi pada masa Orde Baru, baik secara ideologis, geografis maupun demografis. Kini muncul gagasan kelompok tertentu untuk mengganti negara Pancasila dengan negara agama dan menggantikan NKRI dengan sistem agama yang 
dipahami secara sempit. Di samping itu, kini juga muncul upaya-upaya untuk menghidupkan kembali ideologi kiri, yang sebenarnya telah dilarang berdasarkan Tap MPRS No. XXV/1966 tentang Pelarangan PKI dan Ajaran Komunisme, Marxisme dan Leninisme. Menurut mereka, pelarangan ini tidak sesuai dengan hak-hak asasi manusia (HAM) dan sistem demokrasi, yang menjamin adanya persamaan antara semua orang tanpa melihat ras, etnis, agama, ideologi, dsb. Kembalinya ideologiideologi ini dikhawatirkan bisa mengarah kepada konflik sosial dan ancaman terhadap ideologi negara, sebagaimana terjadi pada masa lalu.

Di samping hal tersebut, di era reformasi ini juga muncul ekspresi keagamaan yang lebih konservatif atau lebih liberal, baik atas nama HAM, wawasan kebangsaan sekuler, maupun hanya semata-semata dorongan keuntungan ekonomis. Di samping itu, ekspresi kebebasan yang berbentuk penafsiran doktrin-doktrin agama juga terjadi di sejumlah kampus. Sebagian akademisi mensosialisasikan pemikiran tokoh-tokoh pemikiran Islam liberal dan berlatarbelakang ilmu-ilmu non agama Islam, tanpa terikat dengan metodologi standar. Hal ini dalam beberapa kasus telah menimbulkan ketegangan dan bahkan konflik di antara kelompok-kelompok agama.

Agama dapat memberikan kontribusi positif bagi penguatan wawasan kebangsaan tersebut, terutama dalam revitalisasi ideologi Pancasila serta penguatan integrasi dan harmoni sosial. Oleh karena itu, diperlukan pemahaman agama yang difungsikan sebagai faktor integratif (pemersatu) dan bukan sebagai faktor disintegratif (pemecah belah) bangsa. Untuk mewujudkan fungsi ini, diperlukan pemahaman keagamaan yang moderat dengan memperhatikan kondisi obyektif bangsa Indonesia yang majemuk. Dalam hal ini, seharusnya agama tidak dijadikan sebagai ideologi, tetapi gabungan sebagai sumber ideologi dan sumber etika-moral bangsa Indonesia. Pemahaman semacam ini akan menjelma menjadi sikap keberagamaan yang toleran terhadap kemajemukan, bukan sikap keberagamaan yang berwatak absolutis dan radikal. Dalam hal inilah para tokoh agama, yang meliputi ulama, cendekiawan, muballigh, dan politisi Muslim berusaha untuk mengembangkan Islam moderat (wasathiyyah) ini.

Konsep wasathiyyah mengandung pengertian adanya keseimbangan antara dua sisi yang dimaksud, yang meliputi: (1) keseimbangan antara orientasi Ketuhanan (teosentris) dan orientasi nilai-nilai kemanusiaan (etnosentris), (2) keseimbangan antara penerimaan takdir Allah dan ikhtiar manusia, (3) keseimbangan antara wahyu dan akal (rasio), (3) keseimbangan antara ketetapan (nash-nash) syari'ah dan realitas kehidupan (wâqi'), (4) keseimbangan antara orientasi spiritual (rohani) dan orientasi materiil (jasmani), (5) keseimbangan antara orientasi keagamaan dan kebangsaan, (6) keseimbangan antara solidaritas kelompok dengan pengakuan dan penghormatan terhadap kelompok lain, (7) keseimbangan antara orientasi individual dan orientasi kolektif, (8) keseimbangan antara sikap al-ghuluw (berlebihan) dan sikap taqshîr (pengurangan atau ceroboh), dan (9) keseimbangan antara sikap tasyaddud (memperberat) dan sikap tasâhul (menggampangkan).

Pemahaman wasathiyyah ini bisa tidak sama persis antara satu tempat (negara) dengan tempat (negara) lainnya, karena adanya perbedaan tentang keberadaan dua sisi (pihak) yang berhadapan. Misalnya pemahaman wasathiyyah di negara mayoritas Muslim tidak sama persis dengan pemahaman di negara minoritas Muslim, karena 
realitas kondisi sosial budaya dan sosial politik yang berbeda antara keduanya. Agar pemahaman ajaran-ajaran Islam secara moderat tersebut bisa tepat, diperlukan rambu-rambu yang meliputi: (1) pemahaman Islam secara komprehensif, (2) pemahaman teks Al-Quran dan Hadits serta dinamika masyarakat secara adil dan berimbang (3) dukungan kepada kedamaian dan penghormatan nilai-nilai kemanusiaan, (4) penghormatan terhadap perbedaan pendapat dalam hal-hal yang bersifat ijtihâdiyyah, (5) pengakuan akan pluralitas agama, budaya dan politik, dan (6) pengakuan terhadap hak-hak minoritas. xxii Dengan pemahaman semacam ini, ekspresi ajaran Islam diwujudkan dalam bentuk hubungan sosial yang toleran, akomodatif terhadap negara tetapi tetap kritis terhadap penyelenggaraan negara, serta akomodatif terhadap perkembangan dunia dan tuntutan zaman.

\section{KESIMPULAN}

Uraian di atas dapat disimpulkan, bahwa Indonesia adalah negara demokratis yang berideologi Pancasila, yang notabene menghormati eksistensi agama dalam kehidupan bangsa dan negara. Sebagai ideologi negara, Pancasila merupakan konsensus nasional (al-mitsâq wathanî) dalam rangka mempersatukan bangsa Indonesia, yang notabene merupakan bangsa yang plural, baik dari segi suku, budaya, agama, dan sebagainya. Para tokoh Islam yang terlibat dalam perumusan dasar negara pada tahun 1945 menerima Pancasila, karena secara substantif Pancasila ini sesuai dengan ajaran Islam. Bahkan sila pertama, "Ketuhanan Yang Maha Esa" menunjukkan, bahwa Indonesia bukanlah negara sekuler, tetapi negara modern dan demokratis yang religius.

Ajaran Islam adalah kompatibel dengan demokrasi, dan hal ini telah ditunjukkan terutama oleh Indonesia, Tunisia dan Turki, meski masing-masing negara ini kini masih menghadapi sejumlah permasalahan. Di antara permasalahan di negara ini adalah rendahnya etika politik, munculnya paham-paham atau ideologiideologi fundamentalisme keagamaan yang radikal dan intoleran, maupun ideologi fundamentalisme sekuler. Banyak faktor yang menyebabkan terjadinya radikalisme, ekstremisme, dan terorisme, baik faktor internasional maupun domestik yang meliputi ekonomi, politik dan sosial budaya. Hanya saja, faktor teologis (pemahaman keagamaan) menjadi faktor penting bagi terjadinya sikap ini.

Agama dan negara seharusnya tidak dibenturkan sebagaimana yang dilakukan oleh sebagian gerakan Islam transnasional, melainkan harus diharmonisasikan terutama antara hal-hal yang berbeda antara perspektif Islam dan perspektif Pancasila. Harmonisasi isi dilakukan melalui upaya-upaya pemahaman agama secara moderat, penguatan wawasan kebangsaan, dan revitalisasi ideologi Pancasila dalam kehidupan berbangsa dan bernegara. Sejalan dengan hal ini, perlu dilakukan upayaupaya peningkatan pendidikan dan kesejahteraan rakyat, yang akan berimplikasi pada peningkatan wawasan dan kesadaran akan harmoni dan integrasi bangsa. 


\section{CATATAN AKHIR}

i Cf. Munawir Sjadzali, Islam dan Tata Negara: Ajaran, Sejarah dan Pemikiran, (Jakarta: UI Press, 1990), hlm. 1.

ii Muhammad Yamin (ed.), Naskah Persiapan Undang-Undang Dasar, (Jakarta: Prapanca, 1959), hlm. 151.

iii Yudi Latif, Negara Paripurna: Historitas, Rasionalitas, dan Aktualitas Pancasila, (Jakarta: PT Gramedia, Cetakan keenam, 2017), hlm. 41.

iv Lihat "Ma'ruf Amin: Khilafah Islami, Tapi Tertolak di Indonesia", Republika, 17 Jul 2019.

v Lihat Masykuri Abdillah, Islam dan Dinamika Sosial Politik di Indonesia, (Jakarta: Gramedia Pustaka Utama, 2015), hlm, xv-xviii.

vi Lihat Donald Eugen Smith, Religion and Political Development, (Boston: Little Brown and Company, 1970), h. 124.

vii Masykuri Abdillah, "Hubungan Agama dan Negara dalam Konteks Modernisasi Politik di Era Reformasi", dalam Ahkam, Vol. XIII, No. 2, Juli 2013, hlm. 249.

viii Lihat Alfred Stepan, "Tunisia's Transition and the Twin Tolerations", dalam Journal of Democracy, Vol. 23, No. 2, April 2012, hlm. 69.

ix Cf. Jonathan Fox and Shmuel Sandler, "Separation of Religion and State in the Twenty-First Century", in Comparative Politics, Vol. 37, No. 3, April 2005, hlm. 318.

x Alfred Stepan, "Religion, Democracy, and Twin Tolerations", dalam Journal of Democracy, Vol. 11, No. 4, Oktober 2008, hlm. 41.

xi Alfred Stepan, "Religion ...", hlm. 42.

xii Politik identitas menjadi ancaman yang serius dalam kehidupan politik, termasuk di negara-negara Barat yang praktik demokrasinya sudah lebih maju. Hal ini karena politik identitas akan melanggengkan persaingan dan konflik antar kelompok yang sering disertai dengan ujaran kebencian dan kekerasan. Lihat Mahpudin, "Demokrasi dan Kebangkitan Politik Identitas: Refleksi Perjalanan Demokrasi Pasca Orde Baru", dalam Internasional Jurnal of Demos (IJD), Vol. 1, April 2019.

xiii Menurut Juan Linz dan Alfred Stepan, transisi yang lengkap telah terjadi ketika empat persyaratan terpenuhi, yakni adanya kesepakatan yang memadai tentang prosedur penyelenggaraan pemilu yang demokratis; pemerintah dipilih secara langsung dalam pemilu bebas; pemerintah memiliki kewenangan untuk merumuskan kebijakan; dan tidak ada pembagian kekuasaan di luar eksekutif, legislatif, dan yudikatif. Sedangkan demokrasi yang terkonsolidasi memiliki tiga ciri, yaitu ketika demokrasi itu terinternalisasi baik secara sikap, tingkah laku, maupun konstitusi. Lihat Juan J. Linz dan Alfred Stepan, di http://muse.jhu.edu/journals/journal_of_democracy/v007 / 7.2linz.html.

xiv Tentang perdebatan dan argumentasi tentang kompatibilitas Islam dan demokrasi, lihat Masykuri Abdillah, Islam dan Demokrasi, Respons Intelektual Muslim Indonesia terhadap Konsep Demokrasi, (Jakarta: Prenada Media Grup, 2015).

xv Lihat Al-Wa'ie, No. 151, Tahun XIII, 1-31 Maret 2013.

xvi Pemikiran Syaikh Muhammad bin Abdul Wahhab antara lain dapat dilihat pada kitabnya, Kasyf alSyubuhât li al-Syaikh Muhammad ibn 'Abd al-Wahhâb, (Iskandaria: Dâr al-Îmân), sedangkan pemikiran Sayyid Quthb antara lain dapat dilihat pada kitabnya, Ma'âlim fî al-Tharîq, (Beirut: Dâr al-Syurûq, 1978). xvii Cf. Yudi Latif, Negara Paripurna, hlm. 369-370.

xviii Cf. Moderasi Beragama, (Jakarta: Kementerian Agama RI, 2019), hlm.5-6.

xix Untuk memahami lebih dalam tentang prinsip al-walâ' wa al-barâ', baca Shalih bin Fauzan alFauzan, Al-Walấ' wa al-Barấ' fí al-Islâm, (Gaza: Markaz al-Bahts al-'Ilm Jam'iyyah Dâr al-Kitâb wa alSunnah), dan Muhammad Said Al-Qahthani, (Al-Walâ' wa al-Barâ: Konsep Loyalitas dan Permusuhan dalam Islam, (Jakarta: Ummul Qura, 2013).

xx Lihat Masykuri Abdillah, "Membendung Politisasi Agama", dalam Kompas, 11 Juli 2018. 
xxi Lihat Wawasan Kebangsaan dan Nilai-Nilai Bela Negara, (Jakarta: Lembaga Administrasi Negara RI, 2019), hlm. 22.

xxii Cf. Yusuf al-Qaradhawi, Kalimât fí al-Wasathiyyah al-Islâmiyyah wa Ma'âlimihâ, (Kairo: Dâr al-Syurûq, 2011), hlm. 41-50. 